\title{
O QUINTO DESAFIO DO FÓRUM
}

De volta a Porto Alegre e renovado pela experiência indiana, um encontro traça vôos ambiciosos. Mais participativo e popular, o V Fórum também quer aumentar seu caráter propositivo.

Desde o dia 25 de janeiro de 2001 - quando teve início sua primeira edição -, o Fórum Social Mundial (FSM) acumulou muitas experiências. Foram três encontros no Brasil - de 2001 a 2003 - e outro em 2004, em Mumbai, na Índia. Neste ano, de 26 a 31 de janeiro, o FSM retorna a Porto Alegre, a cidade que o viu nascer.

A quinta edição do encontro será a primeira a colocar em prática uma nova metodologia - que pretende torná-lo mais participativo em sua organização, com maior inserção popular e mais conclusivo em seus debates. "Vamos revitalizar o espírito de Porto Alegre", declara Antonio Martins, um dos representantes da Associação pela Taxação das Transações Financeiras em Apoio ao Cidadão (ATTAC), no Comitê Organizador Brasileiro do Fórum Social Mundial 2005.

Renovado pela experiência indiana, o fórum quer aprofundar ainda mais suas características. Uma novidade no espírito de Porto Alegre 2005 é a vontade declarada pelo Comitê Organizador Brasileiro - responsável pela próxima edição do FSM - de transformar o fórum em um laboratório de alternativas. "Queremos inserir na realização do encontro as práticas que já constroem outro mundo possivel", afirma Gustavo Codas, representante da CUT no FSM. Por isso, na próxima edição, as práticas transformadoras serão mais valorizadas: a maior parte da organização utilizará software livre e os empreendimentos de economia solidária terão prioridade na hora de contratação de serviços ou produtos. Serão levados em consideração os aspectos ecológicos, como a reciclagem de lixo, e será dado destaque maior para a mídia alternativa.

Para tornar a organização do FSM mais participativa, foi feita uma consulta temática entre maio e julho de 2004. Mais de 1.800 organizações responderam, pela internet, quais os debates, sugestões de luta, campanhas, temas e desafios gostariam que fossem debatidos no V FSM. A partir dos resultados da consulta, foram definidos os 11 espaços temáticos do próximo fórum, ou seja, os temas em que se agruparão as atividades (oficina, seminários, painéis, etc.):

1. Firmando e defendendo os bens comuns da Terra e dos povos - Como alternativa à mercantilização e ao controle das transnacionais.

2. Arte e criação: Construindo as culturas de resistência dos povos.

3. Comunicação: Práticas contra-hegemônicas, direitos e alternativas.

4. Defendendo as diversidades, pluralidade e identidades. 
5. Direitos humanos e dignidade para um mundo justo e igualitário.

6. Economias soberanas pelos e para os povos - Contra o capitalismo neoliberal.

7. Ética, cosmovisões e espiritualidades - Resistências e desafios para um novo mundo.

8. Lutas sociais e alternativas democráticas - Contra a dominação neoliberal.

9. Paz e desmilitarização - Luta contra a guerra, o livre comércio e a dívida.

10. Pensamento autônomo, reapropiação e socialização do conhecimento (dos saberes) e das tecnologias.

11. Rumo à construção de uma ordem democrática internacional e integração dos povos.

Também foram identificados três eixos transversais: Emancipação social e dimensão política das lutas, Luta contra o capitalismo patriarcal e Luta contra o racismo.

Com a nova metodologia, a intenção é incentivar a convergência entre organizações com temas comuns. Mais do que isso: permitir que o diálogo e a troca de experiências aconteçam antes mesmo da realização do evento, consolidando essa possibilidade de convergência em um processo o qual tenha continuidade também durante e após o V Fórum Social Mundial.

Mais informações para a imprensa

Escritório do Fórum Social Mundial de Porto Alegre

Jornalistas responsáveis:

Zilda Piovesan e Stela Pastore

Tel: (51) 3227.8622

Escritório do Fórum Social Mundial de São Paulo Jornalista responsável:

Carla Prates

Tel: (11) 3258.8914

fsmimprensa@forumsocialmundial.org.br 